\title{
OPEN Food and nutrition of Gaur (Bos gaurus C.H. Smith, 1827) at the edge of Khao Yai National Park, Thailand
}

\author{
Rattanawat Chaiyarat ${ }^{1}$, Suphat Prasopsin ${ }^{2 \bowtie}$ \& Naris Bhumpakphan ${ }^{3}$
}

The presence of gaur (Bos gaurus) at the border of Khao Yai National Park (KYNP) in Thailand has resulted in a dramatic increase in the number of individuals' crop feeding. This study examines the feeding adaptations of gaur at the edge of the protected area and assesses whether gaur response to increased nutrient availability in crop plants compared to natural forage. During the day, gaur mostly utilized forest areas in KYNP and entered the agricultural areas at night. Gaur ate 43 natural forage species. Natural forage species contain high levels of crude protein and lipid, but they are found in small quantities and scattered areas when compared to crop plants, especially Zea mays L., that are available in large quantity and are heavily foraged on by gaur. However, greater understanding of the electivity index and nutrition of forage species along the edge of the protected area can be used to reduce the gaur-human conflict by keeping gaur in KYNP. Reducing the large monoculture areas that is the food sources of gaur along the edge may reduce or prevent gaur leaving the park and can be applied to advance conservation actions.

Human-wildlife coexistence at the edge of protected areas can create problems that are referred to as humanwildlife conflicts ${ }^{1}$. In general, specialist species are more affected by habitat modification than are generalist species. Moreover, some species are able to change to forage on food species that are more readily available when their preferred forage species are scarce ${ }^{2}$, thereby using crops as an alternative food source. Some crops are attractive to wild animals and provide both energy and nutrition ${ }^{3}$. However, this subject is poorly studied, especially in the large bovids of tropical environments.

Gaur (Bos gaurus), family Bovidae (Fig. 1), is globally vulnerable ${ }^{4}$, and protected under the Thai Reserved and Protected Animals Act, B.C.2562 5 . Gaur are distributed in scattered areas of Bhutan, Cambodia, China, India, Lao PDR, peninsular Malaysia, Myanmar, Nepal, Viet Nam and Thailand. The global population is estimated at 15,000-35,000 animals ${ }^{4}$. In Thailand, an estimated total of 920 Gaur remained in 1994 and none of them were found outside protected areas $^{6}$, but a recent field survey found that the number of gaur are increasing ${ }^{7}$ and entering agricultural areas such as those near Khao Yai National Park (KYNP).

Gaur require a larger habitat area and higher food consumption than do smaller-bodied herbivores ${ }^{8}$. Based on the Jarman-Bell principle, the gaur's large body mass allows it to subsist on lower quality forage than do smaller ruminants, but to meet their caloric demands, gaur require a larger quantity of $\mathrm{it}^{9,10}$. Gaur prefer grassland habitat and open areas of moist evergreen forest, dry evergreen forest, semi-evergreen forest, and mixed deciduous forest ${ }^{11}$. However, Steinmetz ${ }^{12}$ found that gaur are present in dry dipterocarp forest more often than in semi-evergreen forest. In the seasonal forest ecosystems of Thailand and India, gaur live in higher densities in mixed deciduous forests ${ }^{13}$ than in other available habitats ${ }^{14}$ due to the former having a richer array of available food types. This allows them to graze and browse at a single location ${ }^{12}$.

Gaur in Thailand are mainly restricted to protected areas because they are threatened by habitat loss and degradation, as documented in other areas ${ }^{12,14-17}$. When restricted to habitats in protected areas, the ground cover species used as forage, both monocots and dicots, are diminished in abundance. Then, gaur may move to disturbed and open areas along the border of protected areas ${ }^{18,19}$. Agricultural land that is accessible to gaur may be attractive because it meets their forage requirements. This may cause a positive association between gaur and

${ }^{1}$ Wildlife and Plant Research Centre, Faculty of Environment and Resource Studies, Mahidol University, Nakhon Phathom 73170, Nakhon Phathom Province, Thailand. ${ }^{2}$ Mahidol University, Kanchanaburi Campus, Sai Yok District 71150, Kanchanaburi Province, Thailand. ${ }^{3}$ Department of Forest Biology, Faculty of Forestry, Kasetsart University, Chatuchak, Bangkok 10900,Thailand. ${ }^{\circledR}$ email: suphat.pra@mahidol.edu 


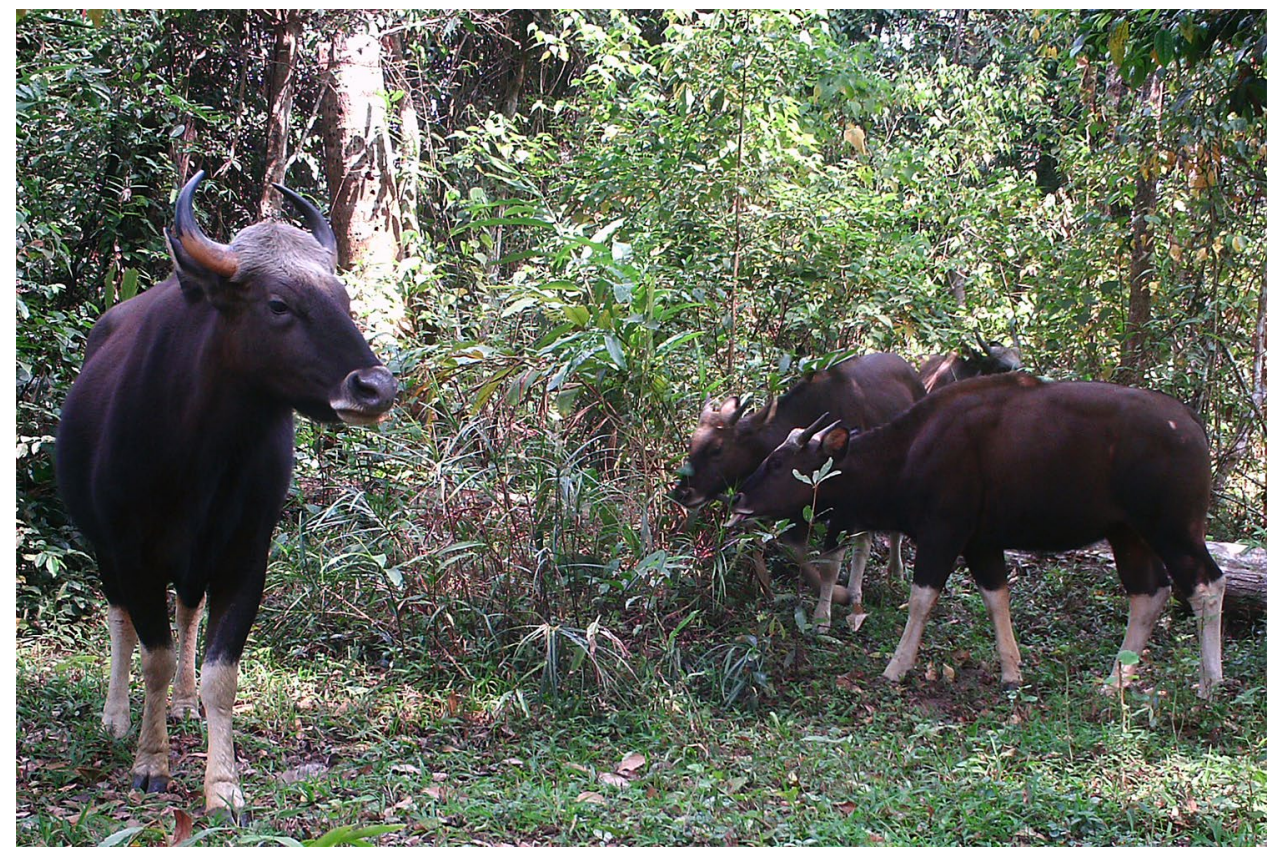

Figure 1. The gaur (Bos gaurus) are the largest extant bovids and feed at the edge of Khao Yai National Park, Thailand. Photographs from camera-trap by R. Chaiyarat.

human settlements. A number of studies found distance to protected edge as an important determinant in cropraiding frequency by ungulates, suggesting that larger populations of wild ungulates lead to more agricultural damage near park edges ${ }^{1}$. The hypothesis that an increasing population of ungulates can cause considerable agricultural damage ${ }^{20}$ is widely believed, but it has never clearly been shown. Unfortunately, there are only a few studies on the food and nutrition of gaur living at the boundary between protected areas and agricultural areas. Crops, especially crop seeds, are high both in energy and palatablity but are low in protein ${ }^{21}$. In this study, we studied natural forage and crop species and nutrition to test the hypothesis that gaur were feeding more on highly nutritious crops grown outside the KYNP than on natural forage species. We investigate the feeding adaptations of gaur at the edge of a protected area and expect that gaur, Bos gaurus, caused crop damage in response to increased nutrient availability in crop plants compared to natural forage.

\section{Materials and methods}

Sample collection. All samples were taken from Khao Yai National Park with the permission from the Department of National Parks, Wildlife and Plant Conservation (DNP0907.1/11504). Research ethics, methods and experimental protocols were approved by the Mahidol University-Institute Animal Care and Use Committee (MU-IACUC 2017/022). Samples were collected and analyzed according to the guidelines of the ethics of wildlife research: A Nine R Theory ${ }^{22}$.

A study on the food and nutrition of gaur in KYNP was conducted in the disturbed edge between Khlong Pla Kang National Park Guard Station (KPK) and Khlong Pla Kang village (KPV), Nakhon Rachasima Province, Thailand between April 2009 and March 2010. Khao Yai National Park was the first national park designated in Thailand and has been listed as an ASEAN Heritage site in 2003 and a UNESCO World Heritage site in 2005. It is located at $14^{\circ} 05^{\prime}-14^{\circ} 15^{\prime} \mathrm{N}$ and $101^{\circ} 05^{\prime}-101^{\circ} 50^{\prime} \mathrm{E}$ with a total area of $2168 \mathrm{~km}^{223}$. Khao Yai National Park is classified into seven forest types: hill evergreen forest (6.7\%), moist evergreen forest (1.9\%), mixed deciduous forest (24.2\%), dry evergreen forest (62.1\%), man-made grassland (1.4\%), dry dipterocarp forest (0.5\%) and secondary forest and other areas $(3.1 \%)^{24}$. These areas are suitable for more than 71 mammal species such as dhole (Cuon alpinus), wild pig (Sus scrofa), sambar (Rusa unicolor), northern red muntjac (Muntiacus vaginalis) and gaur $^{25}$, especially in the area around KPK. The forest types around KPK Station are mixed deciduous forest (48.4\%), dry evergreen forest (49.6\%), and man-made grassland (2\%). Man-made grassland was part of the disturbance areas before KYNP was established and has been maintained as grass food sources for wildlife. The dominant species of trees are dipterocarpaceae. Furthermore, man-made grasslands are found in the abandoned agricultural areas, especially at the edges of the park which are frequently grazed by gaur (Fig. 2).

Field surveys. Field surveys using binoculars (Nikon Aculon A211 8×42) were conducted to determine (a) the percentage of time gaur were observed in each type of forages at the following sites: (1) man-made grassland at wildlife observation tower number two, (2) man-made grassland at wildlife observation area number one, (3) the edge between KPK and the forest, and (4) an agricultural area outside the national park. These locations were chosen in order to compare activities across different habitat types. In each area, the percentage of gaur feeding time between 06:00 AM and 06:00 PM was recorded three days per month for 12 months. In the man-made 


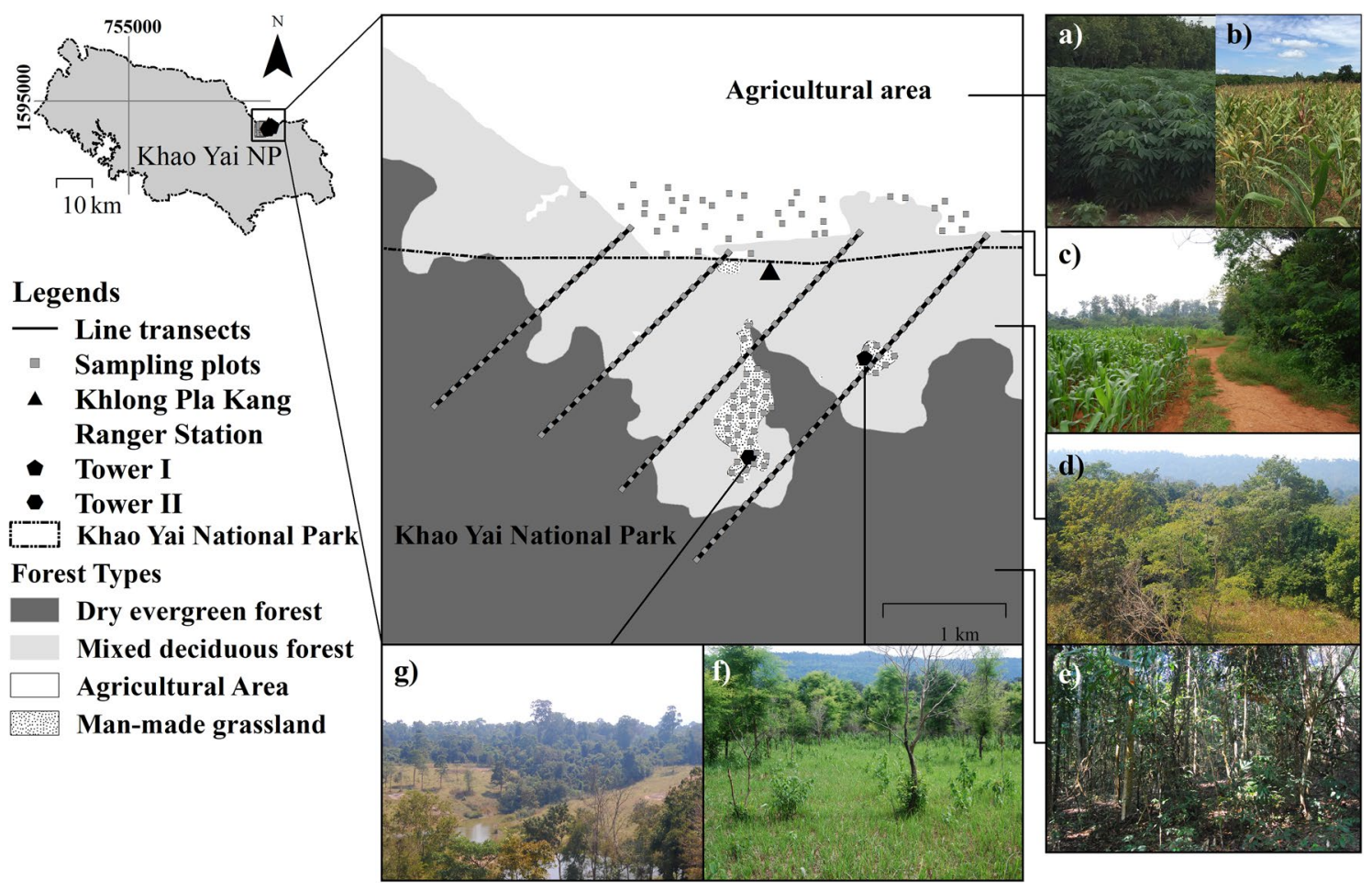

Figure 2. Study area and line transects of gaurs' forage species and nutrition in the edge along Khlong Pla Kang National Park Guard Station, Khao Yai National Park. Maps created using ARC GIS 10.3, modified after Department of National Parks, Wildlife and Plant Conservation (DNP) ${ }^{23}$; (c and f) photographs by S. Prasopsin; all other photographs by R. Chaiyarat.

grasslands, we used the wildlife observation towers, but in the forest areas, each location was selected based on natural signs indicating gaur activity, and we observed from blinds positioned to view the entire feeding area. The frequency of occurrence per area (\%) was calculated from the proportion between the percentage of occurrence and percentage of the area. (b) the percentage of plant species on transect that had been grazed or browsed by gaur. Four transects with a total length of $21 \mathrm{~km}$ were located at the disturbed edge inside the protected area (natural forages) to study the gaurs' food utilization and nutrition. A total of 210 plots $\left(1 \times 2 \mathrm{~m}^{2}\right)$ were sampled along four transects at intervals of $100 \mathrm{~m}$ apart. Most of these sampling plots were located in dry evergreen forest and mixed deciduous forest. In the small paths of man-made grassland and agricultural areas, the areas were crossed with a few line plots. Then, 40 random plots were randomly located and measured in each area in both dry season (November to April) and wet season (May to October) since systematic transect plots at intervals of $100 \mathrm{~m}$ apart from each other were not possible (Fig. 2). All stems (i.e. availability) of each species and number of stems showing evidence of gaur herbivory (i.e. use) were counted and the measurements extrapolated to stems per hectare. All detections of a plant species across the plots were pooled as recommended by Lashley et al. ${ }^{26}$.

To avoid the mistake of misidentifying the foraging of gaur for that of other herbivores, the structure of the damage in remaining forage tissues and the foraging ecology of gaur and other wildlife to distinguish herbivory between gaur and other wildlife species as Lashley et al. ${ }^{27}$ recommended. This method was particularly useful in distinguishing between lagomorphs' indirect bite and that of ungulates. However, distinguishing herbivory between wildlife species can be difficult and may result in sampling errors related to damage detectability that may change with leaf morphology of plant species. To limit false counts of gaur direct bites, only plants with signs of newly eaten vegetation, without necrotic black tissue surrounding the older bite ${ }^{26,27}$, after intensive consideration of the distinctive bite morphology along with new signs of gaur hoof prints in the area, without any other signs of other herbivore species, were recorded. At the disturbed edge area, only gaur, a small population of sambar deer (Rusa unicolor), and elephants (Elephas maximus) were directly observed. Other small nocturnal mammals (e.g. Northern Red Muntjac, Muntiacus vaginalis) or Greater Oriental Chevrotain (Tragulus napu)) were not found or had different forage species and bite behavior. These animals had no impact on the study.

The electivity index of individual forage species consumed. At the end of each season, a twig-count $\operatorname{method}^{28}$ was used to measure the percentage of individual species forage biomass found in the areas. In each consumed species, the diameters of fifty fresh stems at the bite location were measured and averaged. Based on an average stem diameter, fifty fresh stems without bite signs beside the sample plots were clipped and weighed to the nearest $0.01 \mathrm{~g}$. Samples of each plant species, both fresh and consumed, were separated, bagged in plastic and sent to Mahidol University Laboratory at Kanchanaburi Campus. At the laboratory, each sample was put in 


\begin{tabular}{|l|l|l|l|l|}
\hline \multirow{2}{*}{ Occurrence } & Feeding site & a \\
\cline { 2 - 6 } & $\mathbf{1}$ & $\mathbf{2}$ & $\mathbf{3}$ & $\mathbf{4}$ \\
\hline Number of occurrence (times) & 16 & 52 & 35 & 17 \\
\hline Percentage of occurrence (\%) & 13.3 & 43.3 & 29.2 & 14.2 \\
\hline Observed area $\left(\mathrm{km}^{2}\right)$ & 0.06 & 0.31 & 18.5 & 7.7 \\
\hline Percentage of area (\%) & 0.2 & 1.2 & 69.6 & 29 \\
\hline Frequency of occurrence per area (\%) & 60.8 & 38.3 & 0.4 & 0.5 \\
\hline
\end{tabular}

Table 1. Numbers of gaur feeding at the edge along Khlong Pla Kang National Park Guard Station, Khao Yai National Park ( $\mathrm{n}=36$ days). ${ }^{\mathrm{a}}(1)=$ Man-made grassland at wildlife observation tower number 2, (2) Man-made grassland at wildlife observation number 1, (3) Boundary between Khlong Pla Kang National Park Guard Station and agriculture area; this area also served as resting area before going to the agriculture area, and (4) agriculture area outside the national park.

a small paper bag, and dried in an air-flow dryer at $50{ }^{\circ} \mathrm{C}^{27}$ until the weight was unchanged. The weight of each forage species was converted to the biomass for available and consumed in the areas.

The electivity index was calculated by dividing the ratio of use (i.e. stems browsed for bite count and the proportion of the diet for indirect count) and availability (i.e. total number of stems for bite count and available biomass for indirect count) for a given species by the sum of ratios for all species. The Ivlev electivity index ${ }^{29}$ of individual forage species consumed in the study plots was calculated as follows:

$$
E_{i}=\left(r_{i}-P_{i}\right) /\left(r_{i}+P_{i}\right)
$$

where $E_{i}$ is the Ivlev electivity index, $r_{i}$ is the relative removal in each forage species and $P_{i}$ is the relative availability in each species in the ecosystem. $E_{i}$ is scaled so that $E_{i}=-1$ corresponds to total avoidance of, $E_{i}=0$ represents non-selective feeding on, and $E_{i}=1$ shows exclusive feeding on a given forage species $i$.

Food quality assessment. Ten samples of selected plants, including exclusive feeding and avoidance by gaur based on both high and low electivity indices, were collected for natural forage species (inside the protected area) and for agriculture crop plant species (agricultural area). Only new shoots consumed by gaur were selected as samples. All samples were selected in the wet season except for Alstonia scholaris (L.) R.Br. were selected in the dry season as the electivity index of this species was high in the dry season. Ten individual plants ( $100 \mathrm{~g})$ per species were collected and sent to Mahidol University Laboratory at Kanchanaburi Campus for plant nutrient value analysis including the moisture content, ash, crude fiber, crude protein and lipid.

Moisture content was analyzed by oven drying at $105^{\circ} \mathrm{C}$ for $16 \mathrm{hrs}^{30}$. Ash was determined by ashing (Furance, model AWF12/42, Lenton, UK) at $600{ }^{\circ} \mathrm{C}$ for $2 \mathrm{hrs}^{31}$. Fiber was analyzed by used fibertherm (model FT12, Gerhardt, Germany) measurement ${ }^{32}$. Crude protein was determined using Kjeldahl (model KB8, Gerhardt, Germany) nitrogen measurement ${ }^{32}$. Lipid was analyzed using Soxhlet (model S306AK, Gerhardt, Germany) procedures ${ }^{33}$.

Statistical analysis. One-way ANOVA test was used to compare the number among forage species types (tree, shrub, herb, grass, climber, shrubby tree, exotic tree, scandent shrub, under shrub, exotic grass and woody climber) between wet (May to October) and dry (November to April) seasons at the edge using SPSS.

\section{Results}

Detect probabilities to compare observations across habitat types. The gaur grazed more in man-made grassland (43.3\% of observations counted) than in other areas (Table 1). During day time, the relative occurrence per observation area was highest in man-made grassland (60.8\% and $38.3 \%)$ and lowest in the forest between KPK and agricultural areas and where gaur entered agricultural areas at night.

Forage species. A total of 43 natural forage species were recorded in the study area. As many as 41 of these species were consumed by gaur during the wet season, while 25 species were consumed in the dry season. Additionally, 23 species were consumed in both seasons (Tables 2 and 3). The electivity index of natural forage species showed that Ageratum conyzoides L. had the highest value in wet seasons and Chromolaena odorata (L.) R.M. King \& H. Rob. had a high electivity index in both seasons. While crop plants such as Manihot esculenta Crantz had an exclusive electivity index in wet season, and Zea mays L. had an avoid electivity index in wet season, but it was highest in availability and consumption (Table 3 ). The gaur did not show a strong preference in forage species between dicots and monocots or between seasons $(F=0.976 ; d f=3,18 ; p=0.32)$, although dicots were more eaten by gaur in both wet $(80.5 \%)$ and dry $(84 \%)$ seasons (Table 4$)$.

The electivity index of crop damage showed that most crops were consumed in the wet season with a low electivity index. Only Hevea brasiliensis Muell. Arg. was consumed in wet season. Manihot esculenta Crantz was consumed in both seasons (Table 3).

Food quality assessment. Thirteen species (11 wild species and two crop plants) that were noted during direct observation as forage species were sampled. Moisture content, ash, fiber, crude protein and lipid were different among the species $(p<0.05)$. The highest fiber containing plants were Mallotus paniculatus Mull. 


\begin{tabular}{|c|c|c|c|c|c|c|c|}
\hline \multirow[b]{2}{*}{ Family } & \multirow[b]{2}{*}{ Scientific Name } & \multirow[b]{2}{*}{ Forage Species ${ }^{\mathrm{a}}$} & \multirow[b]{2}{*}{ Eaten Part ${ }^{\mathrm{b}}$} & \multicolumn{4}{|c|}{ Habitat type $^{\mathrm{c}}$} \\
\hline & & & & DEF & FP & TGL & AA \\
\hline \multicolumn{8}{|c|}{ Natural forage species } \\
\hline Apocynaceae & Alstonia scholaris (L.) R.Br & $\mathrm{T}$ & $\mathrm{L}, \mathrm{S}$ & $\mathrm{N}$ & $\mathrm{P}$ & $\mathrm{P}$ & A \\
\hline Apocynaceae & Wrightia arborea (Dennst.) Mabb & $\mathrm{T}$ & $\mathrm{L}$ & $\mathrm{P}$ & $\mathrm{P}$ & A & A \\
\hline Asteraceae & Ageratum conyzoides $\mathrm{L}$ & $\mathrm{H}$ & F, S & $\mathrm{P}$ & $\mathrm{P}$ & $\mathrm{P}$ & $\mathrm{P}$ \\
\hline Asteraceae & Chromolaena odorata (L.) R.M. King \& H. Rob & $\mathrm{H}$ & F, S & $\mathrm{P}$ & $\mathrm{P}$ & $\mathrm{P}$ & $\mathrm{P}$ \\
\hline Bignoniaceae & Markhamia stipulata Seem & $\mathrm{T}$ & $\mathrm{L}$ & $\mathrm{P}$ & $\mathrm{P}$ & A & A \\
\hline Combretaceae & Combretum deciduum Collet \& Hemsl & S & $\mathrm{L}$ & $\mathrm{P}$ & $\mathrm{P}$ & A & A \\
\hline Costaceae & Costus speciosus (Koen.) Sm & $\mathrm{H}$ & $\mathrm{L}$ & $\mathrm{P}$ & $\mathrm{P}$ & A & A \\
\hline Cyperaceae & Cyperus sp. & Gs & $\mathrm{L}$ & A & A & $\mathrm{P}$ & A \\
\hline Dilleniaceae & Dillenia obovata (Blume) Hoogland & $\mathrm{T}$ & $\mathrm{L}$ & A & $\mathrm{P}$ & A & A \\
\hline Dioscoreaceae & Dioscorea glabra Roxb & C & $\mathrm{L}$ & A & $\mathrm{P}$ & $\mathrm{P}$ & A \\
\hline Dipterocarpaceae & Dipterocarpus turbinatus C.F. Gaertn & $\mathrm{T}$ & $\mathrm{L}$ & $\mathrm{P}$ & A & A & A \\
\hline Euphorbiaceae & Croton persimilis Mull. Arg & S & S & A & $\mathrm{P}$ & A & A \\
\hline Fabaceae & Acacia catechu (L.f.) Willd & ExT & $\mathrm{L}$ & A & $\mathrm{P}$ & $\mathrm{A}$ & A \\
\hline Fabaceae & Acacia concinna (willd.) DC & ScanS & $\mathrm{L}$ & A & $\mathrm{P}$ & $\mathrm{P}$ & A \\
\hline Fabaceae & Adenanthera pavonina $\mathrm{L}$ & $\mathrm{T}$ & $\mathrm{L}$ & A & $\mathrm{P}$ & A & A \\
\hline Fabaceae & Pterocarpus macrocarpus Kurz & $\mathrm{T}$ & $\mathrm{L}$ & $\mathrm{P}$ & $\mathrm{P}$ & A & A \\
\hline Fabaeae & Xylia xylocarpa (Roxb.) Taub & $\mathrm{T}$ & $\mathrm{L}$ & $\mathrm{P}$ & $\mathrm{P}$ & A & A \\
\hline Irvingiaceae & Irvingia malayana Oliv. Ex A.W.Benn & $\mathrm{T}$ & $\mathrm{L}$ & $\mathrm{P}$ & A & A & A \\
\hline Lauraceae & Cinnamomum iners Reinw. Ex Blume & $\mathrm{T}$ & $\mathrm{L}$ & $\mathrm{P}$ & A & A & A \\
\hline Lauraceae & Litsea glutinosa (Lour.) C.B.Rob & $\mathrm{T}$ & $\mathrm{L}$ & $\mathrm{P}$ & A & A & A \\
\hline Malvaceae & Helicteres lanata (Teijsm. \& Binn.) Kurz & S & $\mathrm{L}$ & $\mathrm{P}$ & $\mathrm{P}$ & $\mathrm{P}$ & A \\
\hline Malvaceae & Mallotus paniculatus Mull. Arg & $\mathrm{T}$ & $\mathrm{L}, \mathrm{S}$ & A & $\mathrm{P}$ & A & A \\
\hline Malvaceae & Mallotus philippensis Mull. Arg & ST & $\mathrm{L}$ & A & $\mathrm{P}$ & $\mathrm{P}$ & A \\
\hline Malvaceae & Microcos paniculata $\mathrm{L}$ & $\mathrm{T}$ & $\mathrm{L}$ & A & $\mathrm{P}$ & A & A \\
\hline Malvaceae & Urena lobata $\mathrm{L}$ & US & $\mathrm{L}$ & A & $\mathrm{P}$ & $\mathrm{P}$ & $\mathrm{P}$ \\
\hline Menispermaceae & Tiliacora triandra (Colebr.) Diels & $\mathrm{H}$ & $\mathrm{L}$ & $\mathrm{P}$ & $\mathrm{P}$ & $\mathrm{A}$ & $\mathrm{A}$ \\
\hline Musaceae & Musa cylindric Colla & $\mathrm{H}$ & $\mathrm{L}, \mathrm{S}$ & A & $\mathrm{P}$ & A & A \\
\hline Oleaceae & Jasminum anodontum Gagnep & C & $\mathrm{L}$ & A & $\mathrm{P}$ & A & A \\
\hline Oleaceae & Jasminum simplicifolium $\mathrm{G}$. Forst & C & $\mathrm{L}$ & A & $\mathrm{P}$ & A & A \\
\hline Phyllanthaeae & Bischofia javanica Blume & $\mathrm{T}$ & $\mathrm{L}$ & A & $\mathrm{P}$ & A & A \\
\hline Phyllanthaceae & Phyllanthus emblica $\mathrm{L}$ & $\mathrm{T}$ & S & A & $\mathrm{P}$ & A & A \\
\hline Phyllanthaceae & Phyllanthus sp.1 & $\mathrm{H}$ & $\mathrm{L}$ & A & $\mathrm{P}$ & $\mathrm{P}$ & A \\
\hline Phyllanthaceae & Phyllanthus sp.2 & S & $\mathrm{L}, \mathrm{S}$ & A & $\mathrm{P}$ & A & A \\
\hline Poaceae & Arundo donax $\mathrm{L}$ & Gs & $\mathrm{L}$ & A & $\mathrm{P}$ & $\mathrm{P}$ & A \\
\hline Poaceae & Brachiaria mutica (Forssk.) Stapf & Gs & $\mathrm{L}$ & A & A & $\mathrm{P}$ & A \\
\hline Poaceae & Imperata cylindrica (L.) Raeusch & Gs & $\mathrm{L}$ & A & $\mathrm{P}$ & $\mathrm{P}$ & $\mathrm{P}$ \\
\hline Poaceae & $\begin{array}{l}\text { Neyraudia reynaudiana (Kunth) H.Keng ex } \\
\text { Hitchc }\end{array}$ & Gs & $\mathrm{L}$ & A & $\mathrm{P}$ & $\mathrm{P}$ & $\mathrm{P}$ \\
\hline Poaceae & Pennisetum polystachyon (L.) Schult & ExGs & $\mathrm{L}$ & A & $\mathrm{P}$ & $\mathrm{P}$ & $\mathrm{P}$ \\
\hline Poaceae & Sorghum halepense (L.) Pers & Gs & $\mathrm{L}$ & A & $\mathrm{P}$ & $\mathrm{P}$ & $\mathrm{P}$ \\
\hline Poaceae & Sorghum propinquum (Kunth) Hitchc & Gs & $\mathrm{L}$ & A & $\mathrm{P}$ & $\mathrm{P}$ & A \\
\hline Rhamnaceae & Ziziphus oenoplia (L.) Mill & WC & $\mathrm{L}$ & A & $\mathrm{P}$ & $\mathrm{P}$ & A \\
\hline Rubiaceae & Ixora umbellate Valeton ex koord & S & S & $\mathrm{P}$ & $\mathrm{P}$ & A & A \\
\hline Simaroubaceae & Harrisonia perforata (Blanco) Merr & ScanS & $\mathrm{L}, \mathrm{S}$ & A & $\mathrm{P}$ & $\mathrm{P}$ & A \\
\hline \multicolumn{8}{|c|}{ Agriculture crop plant } \\
\hline Annonaceae & Annona squamosa L. (Sugar apple) & ExST & $\mathrm{L}, \mathrm{S}$ & A & A & A & $\mathrm{P}$ \\
\hline Euphorbiaceae & $\begin{array}{l}\text { Hevea brasiliensis Muell. Arg. (Pará rubber } \\
\text { tree) }\end{array}$ & ExT & $\mathrm{L}, \mathrm{S}$ & A & A & A & $\mathrm{P}$ \\
\hline Euphorbiaceae & Manihot esculenta Crantz (Cassava) & ExS/ST & $\mathrm{L}, \mathrm{S}$ & A & A & A & $\mathrm{P}$ \\
\hline Myrtaceae & $\begin{array}{l}\text { Eucalyptus camaldulensis Dehnh. (River red } \\
\text { gum) }\end{array}$ & ExT & $\mathrm{L}, \mathrm{S}$ & A & A & A & $\mathrm{P}$ \\
\hline Poaceae & Zea mays L. (Corn) & ExGs & $\mathrm{L}, \mathrm{S}$ & A & A & A & $\mathrm{P}$ \\
\hline Solanaceae & Capsicum annuum L. (Capsicum) & ExS & $\mathrm{L}, \mathrm{S}$ & A & A & A & $\mathrm{P}$ \\
\hline Umbelliferae & Coriandrum sativum L. (Coriander) & ExH & $\mathrm{L}, \mathrm{S}$ & A & A & A & $\mathrm{P}$ \\
\hline
\end{tabular}


Table 2. Species list of gaurs' forage species and their edible parts in the transition zone around Khlong Pla

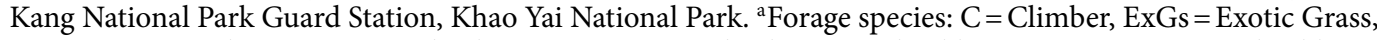
ExH = Exotic Herb, ExS = Exotic Shrub, ExS/ST = Exotic Shrub/Exotic Shrubby Tree, ExST = Exotic Shrubby Tree, ExT = Exotic Tree, Gs = Grass, $\mathrm{H}=$ Herb, $\mathrm{S}=$ Shrub, ScanS $=$ Scandent Shrub, $\mathrm{ST}=$ Shrubby Tree, $\mathrm{T}=\mathrm{Tree}$, US $=$ Under Shrub, WC = Woody Climber. ${ }^{b}$ Part of forage species: $\mathrm{L}=$ Leaf, $\mathrm{F}=$ Flower, $\mathrm{S}=$ Shoot.

Arg. (0.789 $\left.\pm 0.044 \mathrm{mg} \mathrm{g}^{-1}\right)$, Imperata cylindrica (L.) Raeusch. $\left(0.734 \pm 0.054 \mathrm{mg} \mathrm{g}^{-1}\right)$, Manihot esculenta Crantz $\left(0.597 \pm 0.139 \mathrm{mg} \mathrm{g}^{-1}\right)$, and Zea mays L. $\left(0.535 \pm 0.007 \mathrm{mg} \mathrm{g}^{-1}\right)$. The average fiber content of all plants tested was $0.464 \pm 0.185 \mathrm{mg} \mathrm{g}^{-1}$. The plants containing the highest crude protein were Wrightia arborea (Dennst.) Mabb. $\left(0.686 \pm 0.009 \mathrm{mg} \mathrm{g}^{-1}\right)$, Jasminum anodontum Gagnep. $\left(0.392 \pm 0.002 \mathrm{mg} \mathrm{g}^{-1}\right)$, and Ageratum conyzoides L. $\left(0.382 \pm 0.266 \mathrm{mg} \mathrm{g}^{-1}\right)$, while crop plants Manihot esculenta Crantz $(0.11 \pm 0.019 \mathrm{mg} / \mathrm{g})$ and Zea mays L. $\left(0.081 \pm 0.002 \mathrm{mg} \mathrm{g}^{-1}\right)$ contained lower crude protein than average $\left(0.226 \pm 0.214 \mathrm{mg} \mathrm{g}^{-1}\right)(\mathrm{F}=11.842$, df 12 , 26, $p<0.001)$. Moreover, lipid content in Alstonia scholaris (L.) R.Br. $\left(0.064 \pm 0.006 \mathrm{mg} \mathrm{g}^{-1}\right)$, Wrightia arborea (Dennst.) Mabb. (0.057 $\left.\pm 0.002 \mathrm{mg} \mathrm{g}^{-1}\right)$, Mallotus paniculatus Mull. Arg. (0.045 $\left.\pm 0.004 \mathrm{mg} \mathrm{g}^{-1}\right)$, Chromolaena odorata (L.) R.M. King \& H. Rob. $\left(0.035 \pm 0003 \mathrm{mg} \mathrm{g}^{-1}\right)$ and Manihot esculenta Crantz $\left(0.039 \pm 0.000 \mathrm{mg} \mathrm{g}^{-1}\right)$ were higher than average $\left(0.028 \pm 0.019 \mathrm{mg} \mathrm{g}^{-1}\right)(\mathrm{F}=111.28 ; \mathrm{df}=12,26 ; p<0.001)$ (Table 5).

\section{Discussion}

Feeding ecology is an important aspect of understanding the relationships between consumers and their environments ${ }^{34}$ in order to explain the increase in crop raids at the edge of protected areas. Using indirect bite count surveys to calculate the preferences for individual plant species has flaws. We suggest that in diet selection studies, it is preferable to use microhistological surveys together with indirect bite counts to assess the utility of the latter in gaur diet selection (see Holechek et al. ${ }^{35}$ and Lashley et al. ${ }^{26}$ for comparative approaches).

In KPK, gaur sightings occurred mostly in man-made grassland during the day time (06:00 AM and 06.00 PM). Gaur have previously been reported in Northern Kerala, India to enter grassland areas during the night time (06:00 PM-06:00 AM) (Jayson, 2016) ${ }^{36}$. The forage species selected by gaur did not different between dicots and monocots in both dry and wet seasons. These results differed from those reported by Bidayabha ${ }^{18}$ on the gaur population in the Khao Phaeng-Ma Non-Hunting Area (KPM) adjacent to KYNP. The KPK is mainly covered by evergreen and deciduous forests, but the KPM Area was restored mainly from man-made grassland and in 2017 Prayong and Srikosamatara ${ }^{37}$ found forage grass species in KPM were covered by pioneer tree species. There can be large changes in wildlife intake on grassland over different periods ${ }^{38,39}$. In this way, wildlife can show an opportunistic behavior in relation to forage availability ${ }^{40}$. The differences between browsers and grazers extend beyond diet selection; they include specialization within the digestive tract that may allow grazing and browsing herbivores to better extract nutrients from their preferred forage class (grass or browse) ${ }^{41,42}$. Ungulate species have been found to have different food and feeding habits ${ }^{43}$. Gaur, have been described as grazers ${ }^{42,44,45}$, browsers ${ }^{46}$ and generalists ${ }^{47}$ depending on habitat types.

Additionally, the results of our study show that 43 species of plants are consumed by gaur in KPK. Eighteen forage species were absent in the dry season. A change of food preference by animals during the vegetative growth season was clearly pointed out by Fresehi et al. ${ }^{48}$, and this could be due to modification in palatability of forage species according to their different stage of development ${ }^{39}$. It could also be influenced by forage biomass or plants' reaction to utilization, and that reaction can change during growing seasons ${ }^{49}$. In the natural habitat, this process is important in ecology $y^{50}$ and should be accounted for in future studies. This evolution cannot be negative because the utilization of native species by wildlife can occur to a remarkable degree, and species can adapt, in particular situations, to browse on species of reduced forage quality ${ }^{38}$.

The variation in preference rating could be influenced by difference in the plant species and mode of presentation $^{51}$.

For example, the electivity index of natural forage species showed that Ageratum conyzoides L. had the highest value in wet seasons, Chromolaena odorata (L.) R.M. King \& H. Rob. had high electivity index in both seasons. These two species are high in crude protein that induce gaur to select them with a high electivity index, even though Ageratum conyzoides L. was scare and low in biomass per area when compared to other species. Chromolaena odorata (L.) R.M. King \& H. Rob. is available or present in all habitat types, but it emits strong odors and may not be favorable or relished if gaur have other forage choices as explained by Kaitho et al. ${ }^{52}$. In comparison, Wrightia arborea (Dennst.) Mabb. contains the highest crude protein, but it produces a white latex that may not be favorable to gaur. Furthermore, the texture and chemical constituents of the leaves ${ }^{51}$, secondary compounds, macronutrient concentrations, flavors and odors ${ }^{53,54}$ also have been found to be important to preference rating of animals. These factors are not taken into account in this study and are recommended for future study. It should be noted that crop plants such as Manihot esculenta Crantz and Zea mays L. are higher in moisture content and are grown in larger areas as a monoculture as opposed to natural forage that is usually scattered in small areas. Additionally, crude protein in the Manihot esculenta Crantz and Zea mays L. were lower than the average of wild forage species, while lipids were higher than the average of natural forage species. These lipids can give gaur more energy to support their activities in shorter feedings within a large area of crop plants. This finding can support the theory of crop feeding as an optimizing strategy in which gaur choose behavioral strategies that are most likely to give them maximum benefit in comparison with the cost incurred ${ }^{55}$. Gaur may encounter the dangers from agricultural owners when feeding their crops. 


\begin{tabular}{|c|c|c|c|c|c|c|c|}
\hline \multirow[b]{2}{*}{ Family } & \multirow[b]{2}{*}{ Scientific name } & \multicolumn{2}{|c|}{$\begin{array}{l}\text { Available (g } \\
\mathrm{ha}^{-1} \text { ) }\end{array}$} & \multicolumn{2}{|c|}{$\begin{array}{l}\text { Removal ( } \mathrm{g} \\
\mathrm{ha}^{-1} \text { ) }\end{array}$} & \multicolumn{2}{|c|}{ Electivity index } \\
\hline & & Dry & Wet & Dry & Wet & Dry & Wet \\
\hline \multicolumn{8}{|c|}{ Natural forage species } \\
\hline Apocynaceae & Alstonia scholaris (L.) R.Br & 139.2 & 212 & 49.6 & 152.8 & 0.15 & -0.26 \\
\hline Apocynaceae & Wrightia arborea (Dennst.) Mabb & 24.5 & 3.5 & 13.3 & 2.1 & -0.05 & -0.17 \\
\hline Asteraceae & Ageratum conyzoides $\mathrm{L}$ & N/A & 28.8 & N/A & 0.2 & N/A & 0.97 \\
\hline Asteraceae & Chromolaena odorata (L.) R.M. King \& H. Rob & 170.6 & 454.8 & 4.5 & 11.1 & 0.9 & 0.89 \\
\hline Bignoniaceae & Markhamia stipulata Seem & N/A & 14.5 & N/A & 3.5 & N/A & 0.28 \\
\hline Combretaceae & Combretum deciduum Collet \& Hemsl & N/A & 67.2 & N/A & 6.5 & N/A & 0.63 \\
\hline Costaceae & Costus speciosus (Koen.) Sm & N/A & 1.4 & N/A & 0.4 & N/A & 0.2 \\
\hline Cyperaceae & Cyperus sp. & N/A & 151.5 & N/A & 1.3 & N/A & 0.96 \\
\hline Dilleniaceae & Dillenia obovata (Blume) Hoogland & N/A & 1.7 & N/A & 1.7 & N/A & -0.4 \\
\hline Dioscoreaceae & Dioscorea glabra Roxb & 0.6 & 5.6 & 0.6 & 3.4 & -0.35 & -0.7 \\
\hline Dipterocarpaceae & Dipterocarpus turbinatus C.F. Gaertn & 1.2 & N/A & 0.6 & N/A & -0.01 & N/A \\
\hline Euphorbiaceae & Croton persimilis Mull. Arg & N/A & 1.3 & N/A & 0.5 & N/A & 0.05 \\
\hline Fabaceae & Acacia catechu (L.f.) Willd & N/A & 209.1 & N/A & 108.8 & N/A & -0.1 \\
\hline Fabaceae & Acacia concinna (willd.) DC & 73 & 125.8 & 40.5 & 88 & -0.07 & -0.24 \\
\hline Fabaceae & Adenanthera pavonina $\mathrm{L}$ & N/A & 13.6 & N/A & 7.1 & $\mathrm{~N} / \mathrm{A}$ & -0.1 \\
\hline Fabaceae & Pterocarpus macrocarpus Kurz & 4.6 & 21.5 & 0.6 & 16.8 & 0.58 & -0.29 \\
\hline Fabaeae & Xylia xylocarpa (Roxb.) Taub & N/A & 9.3 & N/A & 2.3 & N/A & 0.27 \\
\hline Irvingiaceae & Irvingia malayana Oliv. Ex A.W.Benn & 5.3 & 23.7 & 4.4 & 7.9 & -0.26 & 0.12 \\
\hline Lauraceae & Cinnamomum iners Reinw. Ex Blume & 3.4 & N/A & 3.4 & N/A & -0.35 & N/A \\
\hline Lauraceae & Litsea glutinosa (Lour.) C.B.Rob & 0.4 & 2.9 & 0.2 & 1.2 & -0.01 & 0.02 \\
\hline Malvaceae & Helicteres lanata (Teijsm. \& Binn.) Kurz & N/A & 0.7 & N/A & 0.7 & N/A & -0.4 \\
\hline Malvaceae & Mallotus paniculatus Mull. Arg & 3 & 0.5 & 1.5 & 0.5 & -0.01 & -0.4 \\
\hline Malvaceae & Mallotus philippensis Mull. Arg & 8.4 & 12.7 & 4.2 & 12.7 & -0.01 & -0.4 \\
\hline Malvaceae & Microcos paniculata $\mathrm{L}$ & N/A & 100.4 & N/A & 56.4 & N/A & -0.14 \\
\hline Malvaceae & Urena lobata $\mathrm{L}$ & 58 & 108.6 & 6.5 & 10.5 & 0.63 & 0.63 \\
\hline Menispermaceae & Tiliacora triandra (Colebr.) Diels & N/A & 0.8 & N/A & 0.8 & N/A & -0.4 \\
\hline Musaceae & Musa cylindric Colla & 3.4 & 2.3 & 2.4 & 0.5 & -0.18 & 0.33 \\
\hline Oleaceae & Jasminum anodontum Gagnep & 11.4 & 52 & 6.8 & 47.1 & -0.1 & -0.36 \\
\hline Oleaceae & Jasminum simplicifolium G. Forst & 25.2 & 26.5 & 14.6 & 15.6 & -0.09 & -0.16 \\
\hline Phyllanthaeae & Bischofia javanica Blume & N/A & 8.4 & N/A & 6.4 & N/A & -0.28 \\
\hline Phyllanthaceae & Phyllanthus emblica $\mathrm{L}$ & N/A & 38.4 & N/A & 25.6 & N/A & -0.22 \\
\hline Phyllanthaceae & Phyllanthus sp.1 & 4.3 & 12.5 & 1.7 & 4.3 & 0.1 & 0.11 \\
\hline Phyllanthaceae & Phyllanthus sp.2 & 2.4 & 10.8 & 2 & 9.6 & -0.26 & -0.35 \\
\hline Poaceae & Arundo donax $\mathrm{L}$ & 56.4 & 50.9 & 3.4 & 26.5 & 0.78 & -0.1 \\
\hline Poaceae & Brachiaria mutica (Forssk.) Stapf & N/A & 1.8 & N/A & 0.9 & N/A & -0.08 \\
\hline Poaceae & Imperata cylindrica (L.) Raeusch & N/A & 3638.5 & N/A & 2099.1 & N/A & -0.15 \\
\hline Poaceae & Neyraudia reynaudiana (Kunth) H.Keng ex Hitchc & 59.1 & 14.3 & 53.8 & 11.2 & -0.3 & -0.29 \\
\hline Poaceae & Pennisetum polystachyon (L.) Schult & N/A & 38.7 & N/A & 20.3 & N/A & 0.1 \\
\hline Poaceae & Sorghum halepense (L.) Pers & 16.8 & 26.9 & 4.9 & 11.8 & 0.25 & -0.01 \\
\hline Poaceae & Sorghum propinquum (Kunth) Hitchc & 14.5 & 105.9 & 8.8 & 63.6 & -0.11 & -0.17 \\
\hline Rhamnaceae & Ziziphus oenoplia (L.) Mill & 23 & 127.5 & 4.7 & 63.2 & 0.01 & -0.07 \\
\hline Rubiaceae & Ixora umbellate Valeton ex koord & 5.5 & 21.3 & 2.4 & 10.3 & 0.05 & -0.06 \\
\hline Simaroubaceae & Harrisonia perforata (Blanco) Merr & 229.8 & 499.6 & 162.2 & 385.7 & -0.18 & -0.29 \\
\hline \multicolumn{8}{|c|}{ Agricultural crop plant } \\
\hline Annonaceae & Annona squamosa L. (Sugar apple) & N/A & 65.2 & N/A & 16.6 & $\mathrm{~N} / \mathrm{A}$ & 0.25 \\
\hline Euphorbiaceae & Hevea brasiliensis Muell. Arg. (Pará rubber tree) & 29.9 & N/A & 6.6 & N/A & 0.38 & N/A \\
\hline Euphorbiaceae & Manihot esculenta Crantz (Cassava) & 264 & 264 & 198 & 105 & -0.21 & 0.04 \\
\hline Myrtaceae & Eucalyptus camaldulensis Dehnh. (River red gum) & N/A & 240 & N/A & 60 & N/A & 0.26 \\
\hline Poaceae & Zea mays L. (Corn) & N/A & 2084.8 & N/A & 912.1 & N/A & -0.01 \\
\hline Solanaceae & Capsicum annuum L. (Capsicum) & N/A & 686 & N/A & 196 & N/A & 0.2 \\
\hline Umbelliferae & Coriandrum sativum L. (Coriander) & N/A & 4075.5 & N/A & 1254 & N/A & 0.16 \\
\hline
\end{tabular}

Table 3. Biomass of available, removal and electivity index of gaurs' forage species in transition zone around Khlong Pla Kang National Park Guard Station, Khao Yai National Park. N/A, Not analyzed. 


\begin{tabular}{|c|c|c|c|c|c|c|c|c|c|c|c|c|c|}
\hline \multirow[b]{2}{*}{ Season } & \multicolumn{11}{|c|}{ Forage species (species) } & \multicolumn{2}{|c|}{$\begin{array}{l}\text { Percentage of selection } \\
(\%)\end{array}$} \\
\hline & $\mathbf{T}$ & S & H & G & C & St & Et & Ss & Us & Eg & Wc & Dicots & Monocots \\
\hline Wet & 13 & 5 & 6 & 7 & 3 & 1 & 3 & 2 & 1 & 1 & 1 & 80.5 & 17.4 \\
\hline Dry & 8 & 2 & 3 & 4 & 3 & 1 & 0 & 2 & 1 & 0 & 1 & 84 & 14.8 \\
\hline $\mathrm{F}$ & \multicolumn{13}{|c|}{0.976} \\
\hline $\mathrm{df}$ & \multicolumn{13}{|c|}{3,18} \\
\hline$p$-value & \multicolumn{13}{|c|}{0.426} \\
\hline
\end{tabular}

Table 4. The type of forage species in the wet season and dry season at the edge along Khlong Pla Kang National Park Guard Station, Khao Yai National Park. T = Tree; $\mathrm{S}=$ Shrub; H = Herb; G = Grass; C=Climber; $\mathrm{St}=$ Shrubby tree; $\mathrm{Et}=$ Exotic tree; $\mathrm{Ss}=$ Scandent shrub; Us = Under shrub; Eg = Exotic grass; Wc = Woody climber.

\begin{tabular}{|c|c|c|c|c|c|c|c|}
\hline \multirow[b]{2}{*}{ Scientific name } & \multirow[b]{2}{*}{ Moisture content $(\%)^{\mathrm{a}}$} & \multicolumn{4}{|c|}{ Food quality $\left(\mathrm{mg} \mathrm{g}^{-1}\right)$} & \multicolumn{2}{|c|}{ Electivity index } \\
\hline & & Ash & Fiber & Crude protein & Lipid & Dry & Wet \\
\hline \multicolumn{8}{|l|}{ Natural forage species } \\
\hline $\begin{array}{l}\text { Chromolaena odorata } \\
\text { (L.) R.M. King \& H. } \\
\text { Rob }\end{array}$ & $54.17^{\mathrm{b}}$ & $0.097 \pm 0.001^{\mathrm{d}}$ & $0.277 \pm 0.01^{\mathrm{ab}}$ & $0.101 \pm 0.001^{\mathrm{ab}}$ & $0.035 \pm 0.003^{\mathrm{d}}$ & 0.9 & 0.89 \\
\hline Ageratum conyzoides L & $44.54^{\mathrm{b}}$ & $0.096 \pm 0.001^{\mathrm{d}}$ & $0.359 \pm 0.009^{\mathrm{b}}$ & $0.382 \pm 0.266^{\mathrm{d}}$ & $0.013 \pm 0.005^{\mathrm{abc}}$ & N/A & 0.97 \\
\hline $\begin{array}{l}\text { Alstonia scholaris (L.) } \\
\text { R.Br }\end{array}$ & $68^{c}$ & $0.154 \pm 0.001 \mathrm{f}$ & $0.466 \pm 0.091^{b c}$ & $0.06 \pm 0.001^{\mathrm{a}}$ & $0.064 \pm 0.006 f$ & 0.15 & -0.26 \\
\hline $\begin{array}{l}\text { Croton persimilis Mull. } \\
\text { Arg }\end{array}$ & $46.43^{\mathrm{b}}$ & $0.106 \pm 0.001^{\mathrm{e}}$ & $0.388 \pm 0.005^{\mathrm{b}}$ & $0.083 \pm 0.001^{\mathrm{a}}$ & $0.02 \pm 0.001^{c}$ & N/A & 0.05 \\
\hline $\begin{array}{l}\text { Mallotus paniculatus } \\
\text { Mull. Arg }\end{array}$ & $63.64^{c}$ & $0.08 \pm 0.001^{c}$ & $0.789 \pm 0.044^{\mathrm{d}}$ & $0.229 \pm 0.22^{b c}$ & $0.045 \pm 0.004^{\mathrm{e}}$ & -0.01 & -0.4 \\
\hline $\begin{array}{l}\text { Wrightia arborea } \\
\text { (Dennst.) Mabb }\end{array}$ & $36.36^{\mathrm{b}}$ & $0.092 \pm 0.000^{\mathrm{d}}$ & $0.349 \pm 0.001^{\mathrm{b}}$ & $0.686 \pm 0.009^{e}$ & $0.057 \pm 0.002 \mathrm{f}$ & -0.05 & -0.17 \\
\hline $\begin{array}{l}\text { Jasminum anodontum } \\
\text { Gagnep }\end{array}$ & $40.41^{\mathrm{b}}$ & $0.057 \pm 0.001^{\mathrm{b}}$ & $0.339 \pm 0.007^{\mathrm{b}}$ & $0.392 \pm 0.002^{\mathrm{d}}$ & $0.014 \pm 0.003^{\mathrm{abc}}$ & -0.1 & -0.36 \\
\hline Microcos paniculata $\mathrm{L}$ & $34.02^{\mathrm{b}}$ & $0.058 \pm 0.004^{\mathrm{b}}$ & $0.071 \pm 0.089^{\mathrm{a}}$ & $0.119 \pm 0.001^{\mathrm{ab}}$ & $0.008 \pm 0.001^{\mathrm{ab}}$ & $\mathrm{N} / \mathrm{A}$ & -0.14 \\
\hline $\begin{array}{l}\text { Imperata cylindrica (L.) } \\
\text { Raeusch }\end{array}$ & $14.71^{\mathrm{a}}$ & $0.059 \pm 0.001^{\mathrm{b}}$ & $0.734 \pm 0.054^{\mathrm{d}}$ & $0.036 \pm 0.007^{\mathrm{a}}$ & $0.018 \pm 0.001^{b c}$ & $\mathrm{~N} / \mathrm{A}$ & -0.15 \\
\hline $\begin{array}{l}\text { Harrisonia perforata } \\
\text { (Blanco) Merr }\end{array}$ & $47.22^{\mathrm{b}}$ & $0.057 \pm 0.001^{\mathrm{b}}$ & $0.364 \pm 0.07^{\mathrm{b}}$ & $0.075 \pm 0.001^{\mathrm{ab}}$ & $0.006 \pm 0.003^{\mathrm{a}}$ & -0.18 & -0.29 \\
\hline Phyllanthus emblica L & $19.8^{\mathrm{a}}$ & $0.027 \pm 0.004^{\mathrm{a}}$ & $0.332 \pm 0.003^{\mathrm{b}}$ & $0.328 \pm 0.006^{\mathrm{d}}$ & $0.023 \pm 0.004^{c}$ & N/A & -0.22 \\
\hline Mean \pm s.d & $42.66 \pm 15.84$ & $0.08 \pm 0.033$ & $0.464 \pm 0.185$ & $0.226 \pm 0.214$ & $0.028 \pm 0.019$ & & \\
\hline \multicolumn{8}{|l|}{ Agriculture crop plant } \\
\hline $\begin{array}{l}\text { Manihot esculenta } \\
\text { Crantz }\end{array}$ & $68.48 \pm 6.48^{c}$ & $0.123 \pm 0.002 f$ & $0.597 \pm 0.139^{c}$ & $0.11 \pm 0.019^{\mathrm{ab}}$ & $0.039 \pm 0.000^{\mathrm{de}}$ & -0.21 & 0.04 \\
\hline Zea mays $\mathrm{L}$ & $73.67 \pm 3.4^{c}$ & $0.119 \pm 0.002 f$ & $0.535 \pm 0.007^{c}$ & $0.081 \pm 0.002^{\mathrm{ab}}$ & $0.01 \pm 0.004^{\mathrm{ab}}$ & N/A & -0.01 \\
\hline $\mathrm{F}$ & 246.331 & 1094.632 & 2.404 & 11.842 & 101.016 & & \\
\hline $\mathrm{df}$ & 12,26 & 12,26 & 12,26 & 12,26 & 12,26 & & \\
\hline$p$-value & $<0.001$ & $<0.001$ & 0.025 & $<0.001$ & $<0.001$ & & \\
\hline
\end{tabular}

Table 5. Food quality of gaur foods in the transition zone around Khlong Pla Kang National Park Guard Station, Khao Yai National Park $(n=3)$. (mean $+s d), a=s d<0.001, N / A=$ not analyzed due to not found consumed.

Our results at the edge of KPK indicated that gaur were entering the agriculture areas at higher rates in the wet season (May to October). Because most crop plants are dependent on rainfall ${ }^{36,50}$, they are grown in the wet season and harvested in the dry season. The mineral content in consumed species ( $>80 \%$ dicots) was higher in KYNP than in gaur dietary items in Bhagvan Mahaveer Wildlife Sanctuary and Mollem National Park, India (>60\% monocots) $)^{16}$ presumably due to different geographical and variation in the plant community (more open area than KPK). In spite of the forage quality of crop plants such as Manihot esculenta Crantz and Zea mays L. In early the wet season, the quality of crop plants are nearly equal when compared to natural species, but late in the wet season, the quality of natural species were dropped off much faster than crop plants. During this period, the availability of crop plants at the edge of KPK may have contributed to the crop raiding and gaur-human conflict in the area, since the forage availability in KYNP has sparse amounts of low herbaceous ground cover 
and grass that are the main forage species of gaur ${ }^{56}$. Retamosa et al. ${ }^{57}$ suggested that reliance on crops will be increased when crop plants such as Zea mays L. are located close to the woodland as found at the edge of KPK.

The primary conservation technique used at the edge was managing grasslands to improve the quantity and quality of grasses and other food plants for successful and sustainable conservation of gaur. The critical problem is to have cooperation of local residents to mitigate conflicts of interest ${ }^{58}$ between conservation and economics. Improving public awareness by conducting outreach programs and strict law enforcement by patrolling combined with habitat management along the habitat site might reduce human and gaur conflict in the area.

This study suggests that gaur living in edge areas are generalists and consume forage species as opportunists. Gaur entered the agricultural areas at the edge of the protected area, even though the food quality of crop species was lower than the average of natural forage species. Manihot esculenta Crantz is the main crop damaged in the area as they are high in crude protein and lipid. Growing crops in the large areas beside the protected area in the wet season will induce gaur to move to these areas and can increase gaur-human conflict in the future. Finally, this research may be used to improve knowledge on gaur feeding behavior and food quality. Which have relevance for future-planned management and conservation to improve the habitat quality of the gaur population in the areas and reduce the large areas of monocrop around the edge of the protected areas to improve farmer vigilance and increase benefits for farmers who have to live next to this protected area.

Received: 25 June 2020; Accepted: 21 January 2021

Published online: 08 February 2021

\section{References}

1. Guerbois, C., Chapanda, E. \& Fritz, H. Combining multi-scale socio-ecological approaches to understand the susceptibility of subsistence farmers to elephant crop raiding on the edge of a protected area. J. Appl. Ecol. 49, 1149-1158 (2012).

2. Felton, A. M. et al. Protein content of diets dictates the daily energy intake of a free-ranging primate. Behav. Ecol. 20, 685-690 (2009).

3. Rode, K. D., Chiyo, P. I., Chapman, C. A. \& McDowell, L. R. Nutritional ecology of elephants in Kibale National Park, Uganda, and its relationship with crop-raiding behaviour. J. Trop. Ecol. 22, 441-449 (2006).

4. Duckworth, J. W., Sankar, K., Williams, A. C., Kumar, N. S. \& Timmins, R. J. Bos gaurus. The IUCN Red List of Threatened Species 2016, e.T2891A46363646 (2016).

5. Royal Thai Government Gazette. Wildlife Preservation and Protection Act, B.E.2562 (2019) of Thailand. www.ratchakitcha.soc. go.th (2019, in Thai).

6. Srikosamatara, S. \& Suteethorn, V. Populations of gaur and banteng and their management in Thailand. Nat. His. Bull. Siam Soc. 43(1), 55-83 (1995).

7. Laichanthuek, P., Sukmasuang, R. \& Duengkae, P. Population and habitat use of gaur (Bos gaurus) around Khao Phaeng Ma Nonhunting Area, Nakhon Ratchasima Province. J. Wildl. Thailand 24, 83-95 (2017).

8. Chetri, M. Diet analysis of gaur, Bos gaurus gaurus (Smith, 1827) by micro-histological analysis of fecal samples in Parsa Wildlife Reserve, Nepal. Our Nat. 4, 20-28 (2006).

9. Bell, R. H. V. The use of the herb layer by grazing ungulates in Serangeti. In Watson, A. (Ed.). Animal Population in Relation to Their Food Resources. (Blackwell Scientific Publication 1970).

10. Jarman, P. J. The social organization of antelope in relation to their ecology. Behaviour 48, 215-266 (1974).

11. Bhumpakphan, N. \& McShea, W. J. Ecology of gaur and banteng in the seasonally dry forests of Thailand. In: McShea, W. J., Davies, S. J. \& Bhumpakphan, N. (Eds.). The Ecology and Conservation of Seasonally Dry Forests in Asia. (Rowman and Littlefield Publishers, Inc. and Smithsonian Institution Scholarly Press 2011).

12. Steinmetz, R. Gaur (Bos gaurus) and banteng (Bos javanicus) in the lowland forest mosaic of Xe Pian Protection Area, Lao PDR: Abundance, habitat use and conservation. Mammalia 68, 141-157 (2004).

13. Karanth, K. U. \& Sunquist, M. E. Population structure, density and biomass of large herbivores in the tropical forests of Nagarahole, India. J. Trop. Ecol. 8, 21-35 (1992).

14. Steinmetz, R. Ecological surveys, monitoring, and the role of local people in protected areas of Lao PDR. (International Institute for Environment and Development 2000).

15. Choudhury, A. Distribution and conservation of gaur Bos gaurus in the Indian Subcontinent. Mammal. Rev. 12, 199-226 (2002).

16. Gad, S. D. \& Shyama, S. K. Diet composition and quality in Indian bison (Bos gaurus) based on fecal analysis. Zool. Sci. 28(4), 264-267 (2011).

17. Velho, N., Srinivasan, U., Singh, P. \& Laurance, W. F. Large mammal use of protected and community-managed lands in a biodiversity hotspot. Anim. Conserv. https://doi.org/10.1111/acv.12234 (2015).

18. Bidayabha, T. Ecology and behavior of gaur (Bos gaurus) in a degraded area at Khao Phaeng-Ma, the Northestern Edge of Khao Yai National Park. (Faculty of Biology, Mahidol University 2001).

19. Panusittikorn, P. \& Prato, T. Conservation of protected areas in Thailand: the case of Khao Yai National Park, protected areas in East Asia. George Wright Forum 18(2), 66-76 (2001).

20. Sorensen, A. A., van Beest, F. M. \& Brook, R. K. Quantifying overlap in crop selection patterns among three sympatric ungulates in an agricultural landscape. Basic App. Ecol. 16, 601-609 (2015).

21. Todorov, N. A. Cereals, pulses and oilseeds. Livestock Produc. Sci. 19, 47-95 (1988).

22. Curzer, H. J., Wallace, M. C., Perry, G., Muhlberger, P. J. \& Perry, D. The ethics of wildlife research: a nine R theory. ILAR J. 54(1), 52-57 (2013).

23. Department of National Parks, Wildlife and Plant Conservation (DNP). Management plan for Dong Phayayen-Khao Yai Forest Complex. (Department of National Parks, Wildlife, and Plant Conservation 2006).

24. Kao-mim, N. Use of Hyperspectral Imaging System Data from HJ - 1A Satellite for Forest Types Classification in Khao Yai National Park. (MS thesis, Kasetsart University 2018, in Thai).

25. Ngoprasert, D. \& Gale, G. A. Tiger density, dhole occupancy, and prey occupancy in the human disturbed Dong Phayayen - Khao Yai Forest Complex, Thailand. Mamm. Biol. 95, 51-58 (2019).

26. Lashley, M. A., Chitwood, M. C., Street, G. M., Moorman, C. E. \& DePerno, C. S. Do indirect bite count surveys accurately represent diet selection of white-tailed deer in a forested environment?. Wildl. Res. 43, 254-260 (2016).

27. Lashley, M. A., Chitwood, M. C., Harper, C. A., Moorman, C. E. \& DePerno, C. S. Collection, handling and analysis of forages for concentrate selectors. Wildl. Biol. Prac. 10(1), 6-15 (2014).

28. Shafer, E. L. Jr. The twig-count method for measuring hardwood deer browse. J. Wildl. Manag. 27(3), 428-437 (1963).

29. Ivlev, V. S. Experimental Ecology of the Feeding of Fishes. (Yale University Press 1961).

30. Association of Official Analytical Chemists (AOAC). Guidelines for collaborative study procedure to validate characteristics of a method of analysis. J. Assoc. Off. Anal. Chem. 71, 161-171 (1988). 
31. Petterson, D. S., Harris, D. J., Rayner, C. J., Blakeney, A. B. \& Choct, M. Methods for the analysis of premium livestock grains. Aus. J Agric. Res. 50, 775-787 (1999).

32. Midkiff, V. A century of analytical excellence. The history of feed analysis, as chronicled in the development of AOAC official methods, 1884-1984. J. Assoc. Off. Anal. Chem. 67, 851-860 (1984).

33. Brown, R. H. \& Mueller-Harvey, I. Evaluation of the novel Soxflo technique for rapid extraction of crude fat in foods and animal feeds. J. AOAC Int. 82, 1369-1374 (1999).

34. Leopold, B. D. \& Krausman, P. R. Diurnal activity patterns of desert mule deer in relation to temperature. Texas J. Sci. 39, 49-53 (1987).

35. Holechek, J. L., Vavra, M. \& Pieper, R. D. Botanical composition determination of range herbivore diets: a review. J. Range Manag. 35(3), 309-315 (1982).

36. Jayson, E. A. Assessment of Human-Wildlife Conflict and Mitigation Measures in Northern Kerala: Final Report of the Research Project KFRI/653/12. (Kerala Forest Research Institute 2016).

37. Prayong, N. \& Srikosamatara, S. Cutting trees in a secondary forest to increase gaur Bos gaurus numbers in Khao Phaeng Ma Reforestation area, Nakhon Ratchasima Province, Thailand. Conserv. Evid. 14, 5-9 (2017).

38. Cervasio, F., Argenti, G., Genghini, M. \& Ponzetta, M. P. Agronomic methods for mountain grassland habitat restoration for faunistic purposes in a protected area of the northern Apennines (Italy). iForest 9, 490-496 (2016).

39. Argenti, G., Racanelli, V., Bartolozzi, S., Staglianò, N. \& Guerri, F. S. Evaluation of wild animals browsing preferences in forage resources. Ital. J. Agron. 12, 884 (2017).

40. Freschi, P. et al. Diet composition of the Italian roe deer (Capreolus capreolus italicus) (Mammalia: Cervidae) from two protected areas. Eur. Zool. J. 84, 34-42 (2017).

41. Robbins, C. T., Spalinger, D. E. \& van Hoven, W. Adaptation of ruminants to browse and grass diets: are anatomical-based browsergrazer interpretations valid?. Oecologia 103, 208-213 (1995).

42. Ahrestani, F. S., Heitkönig, I. M. A., Matsubayashi, H. \& Prins, H. H. T. 2016. Grazing and browsing by large herbivores in South and Southeast Asia. In: Ahrestani, F. S. \& Sankaran, M. (Eds). The ecology of large herbivores in South and Southeast Asia. Ecol. Stud. 225 (2016).

43. Krishnan, M. An ecological survey of the large mammals of Peninsular India. J. Bombay Nat. His. Soc. 69, 297-315 (1972).

44. Ahrestani, F. S. et al. Estimating densities of large herbivores in tropical forests: rigorous evaluation of a dung-based method. Ecol. Evol. 8, 7312-7322 (2018).

45. Ahrestani, F. S. Bos gaurus (Artiodactyla: Bovidae). Mamm. Species 50, 34-50 (2018).

46. Nayak, B. K. \& Patra, A. K. Food and feeding habits of Indian bison, Bos gaurus (Smith, 1827) in Kuldiha Wildlife Sanctuary, Balasore, Odisha, India and its conservation. Int. Res. J. Biol. Sci. 4(5), 73-79 (2015).

47. Gad, S. D. \& Shyama, S. K. Studies on the food and feeding habits of gaur Bos gaurus H Smith (Mammalia: Artiodactyla: Bovidae) in two protected areas of Goa. J. Threat. Taxa 1, 128-130 (2009).

48. Fresehi, P., Riccioli, F., Argenti, G. \& Ponzetta, M. P. The sustainability of wildlife in agroforestry land. Agric. Agric. Sci. Proc. 8, 148-157 (2016).

49. Moser, B., Schutz, M. \& Hindenlang, K. E. Resource selection by roe deer: Are wind throw gaps attractive feeding places?. For. Ecol. Manag. 255, 1179-1185 (2008).

50. Wilsey, B. J. \& Martin, L. M. Top-down control of rare species abundances by native ungulates in a grassland restoration. Restor. Ecol. 23, 465-472 (2015).

51. Kouch, T., Preston, T. R. \& Ly, J. Studies on utilization of trees and shrubs as the sole feedstuff by growing goats; foliage preferences and nutrient utilization. Livestock Res. Rural Dev. 15(7), http://www.lrrd.org/irrd15/7/kouc157.htm (2003).

52. Kaitho, R. J. et al. Palatability of multipurpose tree species: effect of species and length of study on intake and relative palatability by sheep. Agrofor. Syst. 33, 249-261 (1996).

53. Kaitho, R. J. et al. Palatability of wilted and dried multipurpose tree species fed to sheep and goats. Anim. Feed Sci. Technol. 65, 151-163 (1997).

54. Provenza, M. P., Cervasio, F., Crocetti, C., Messeri, A. \& Argenti, G. Habitat improvements with wildlife purposes in a grazed area on the Apennine mountains. Ital. J. Agron. 5, 233-238 (2003).

55. Lucas, J. R. Role of foraging time constraints and variable prey encounter in optimal diet choice. Am. Nat. 122(2), 191-209 (1983).

56. Poapongsakorn, N., Ruhs, M. \& Tangjitwisuth, S. Problems and outlook of agriculture in Thailand. TDRI Quar. Rev. 13(2), 3-14 (1998).

57. Retamosa, M. I., Humberg, L. A., Beasley, J. C. \& Rhodes, O. E. Jr. Modeling wildlife damage to crops in northern Indiana. HumanWild. Conf. 2(2), 225-239 (2008).

58. Su, K., Ren, J., Yang, J., Hou, Y. \& Wen, Y. Human-Elephant conflicts and villagers' attitudes and knowledge in the Xishuangbanna Nature Reserve, China. Inter. J. Environ. Res. Public Health. https://doi.org/10.3390/ijerph17238910 (2020).

\section{Acknowledgements}

We would like to thank Mr. Thaweesak Poyarot and the Royal Highway Department for support us during field survey. We thank the head and staff of Khlong Pla Kang National Park Ranger Station, Khao Yai National Park, and staff of the Gaur Protection Volunteer Club, Mr. Paiboolya Eaimlaong, Mr. Wichiar Suwanapantha, Mr. Daoloi Eaimlaong, and all villages that supported and participated in this research. Our appreciation and thanks to Dr. Thomas N. Stewart, Faculty of Environment and Resource Studies, Mahidol University, Thailand and Larry M. Page, Curator of Fishes, Florida Museum, for English editing and friendship.

\section{Author contributions}

R.C. and S.P. conceived the research and designed the experiments. N.B. and R.C. performed the experiments. R.C. and S.P. analyzed the data, wrote the article and edited the manuscript. All authors read and approved the final manuscript and agree to authorship and submission of the manuscript for peer review.

\section{Competing interests}

The authors declare no competing interests.

\section{Additional information}

Correspondence and requests for materials should be addressed to S.P.

Reprints and permissions information is available at www.nature.com/reprints. 
Publisher's note Springer Nature remains neutral with regard to jurisdictional claims in published maps and institutional affiliations.

(c) (1) Open Access This article is licensed under a Creative Commons Attribution 4.0 International License, which permits use, sharing, adaptation, distribution and reproduction in any medium or format, as long as you give appropriate credit to the original author(s) and the source, provide a link to the Creative Commons licence, and indicate if changes were made. The images or other third party material in this article are included in the article's Creative Commons licence, unless indicated otherwise in a credit line to the material. If material is not included in the article's Creative Commons licence and your intended use is not permitted by statutory regulation or exceeds the permitted use, you will need to obtain permission directly from the copyright holder. To view a copy of this licence, visit http://creativecommons.org/licenses/by/4.0/.

(C) The Author(s) 2021 